\title{
SERUM FREE FATTY ACID AND BLOOD SUGAR LEVELS \\ IN CHILDREN UNDER HALOTHANE, THIOPENTONE AND KETAMINE ANAESTHESIA (Comparative Study)
}

\author{
P. Kaniaris, D. LeKakis, M. Kykoniatis, and E. Kastanas
}

OVER THE LAST TWENTY YEARS, several anaesthetic agents have been introduced to everyday anaesthetic practice. Some of them, like thiopentene sodium and halothane have proven themselves to be successful drugs. Nevertheless, even they remain under clinical and experimental investigation and controversies exist among investigators regarding some of their effects. ${ }^{1-6}$

Ketamine hydrochloride is the newest of the induction agents and because of its special pharmacological properties has become a very important drug, especially in paediatric anaesthesia. Knowledge of the effects of ketamine upon body metabolism are very limited and we have found only one study of its effects on serum free fatty acid and blood sugar levels. ${ }^{7}$

In the present study we have attempted to investigate the effects of halothane, thiopentone and ketamine anaesthesia upon these two serum constituents in children and to compare the results in each group of patients in relation to the given drug.

\section{Material and Method}

Thirty healthy children were selected for our study. They had been admitted to hospital for minor surgical problems such as inguinal hernia and hydrocele. Special attention was directed towards the selection of our patients, including only those who were free of hereditary disease such as haemolytic anaemia, syphilis or endocrinological abnormalities involving thyroid, pancreas or adrenal glands. Children with acute or chronic cardiovascular and respiratory disease were also excluded from the study. The average weight of the patients was 37 kilograms and they were from 10 to 12 years of age. Premedication was the same for all patients, consisting of atropine $0.4 \mathrm{mg}$ and promethazine $1 \mathrm{mg} / \mathrm{kg}$ body weight, 30 minutes before the start of the operation. After transfer to the anaesthesia room and after routine preparation, an intravenous infusion of normal saline was commenced. The thirty children were divided into three groups of ten each. The first group was anaesthetized with halothane 0.5 per cent to 1.5 per cent, supplemented by nitrous oxide and oxygen $5: 3, \mathrm{v} / \mathrm{v}$. The second group were given thiopentone, 3 to $5 \mathrm{mg} / \mathrm{kg}$ body weight supplemented also by nitrous oxide: oxygen, $5: 3, \mathrm{v} / \mathrm{v}$. The third group received ketamine $2 \mathrm{mg} / \mathrm{kg}$ body weight supplemented by nitrous oxide:oxygen as in the other groups.

From the Department of. Experimental Pharmacology, Division of Anaesthesiology, Medical School, The University of Athens, Greece.

Address for reprints: 43, Meandroupoleos Street, Athens, 605, Greece. 


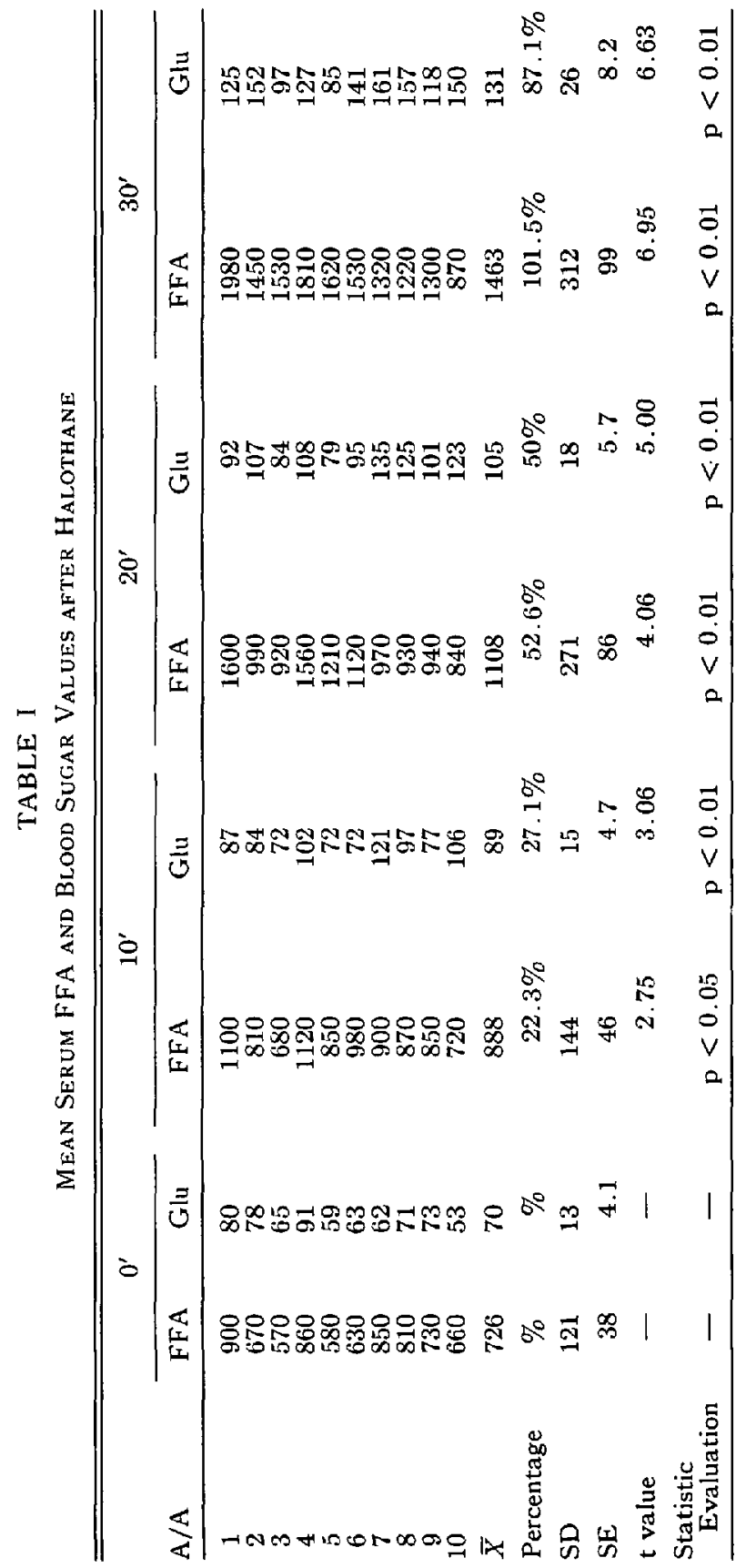


FIG. 1

FIG. 2

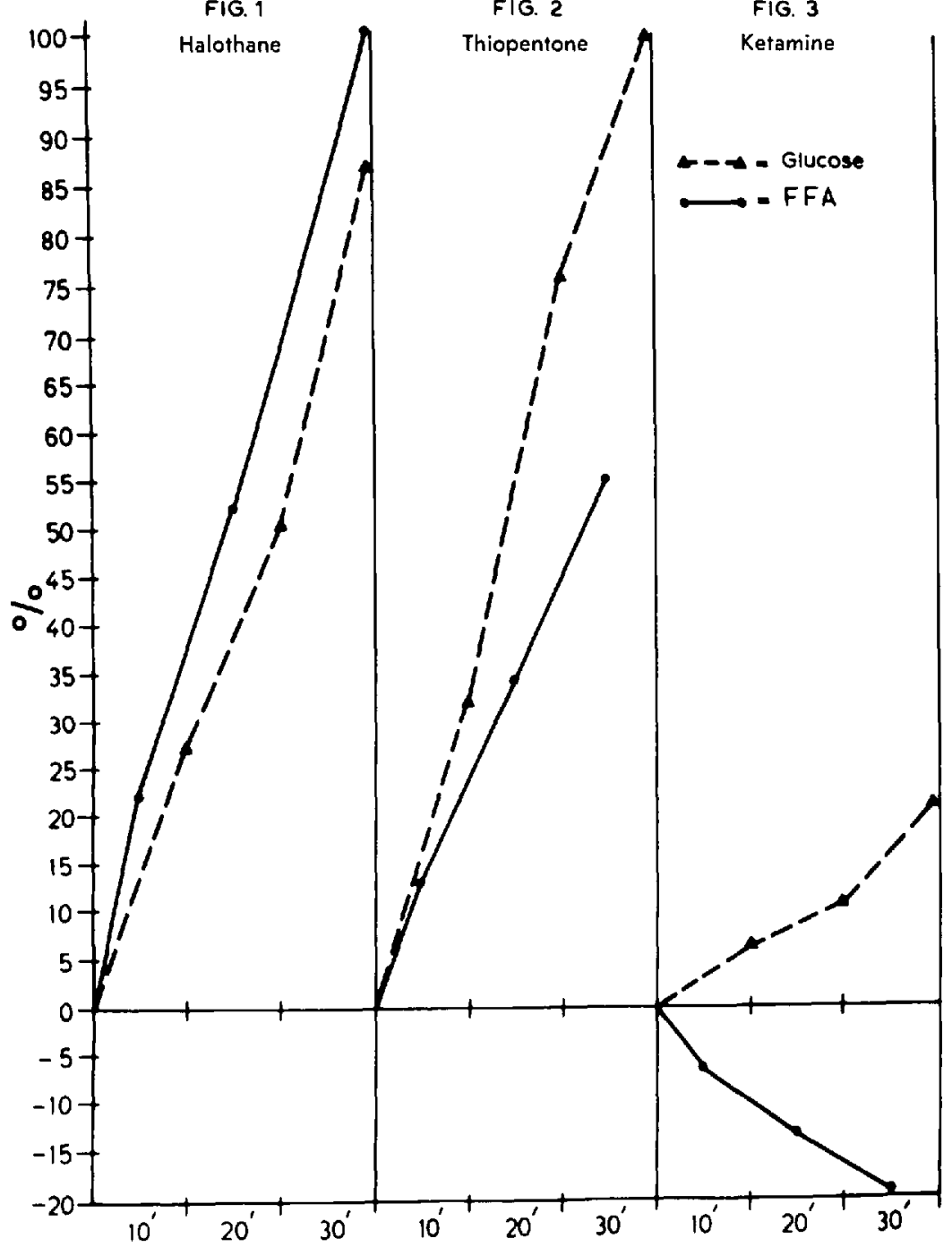

In all the patients, blood specimens were taken for free fatty acid and blood sugar determinations prior to induction as control, and then after induction and at 10,20 and 30 minutes during the surgical procedure. The duration of anaesthesia exceeded one hour.

There was no incident in the course of anaesthesia of hypoxia, vomiting, bronchospasm, laryngospasm, or any other abnormality that could have affected results by increasing the $\mathrm{Paco}_{2}$ or by disturbing autonomic balance. Blood gas determinations were not done due to technical reasons. Serum free fatty acid determinations were done by means of Duncomb's and Howorth's colorometric technique. ${ }^{8.9}$ Blood sugar determinations followed Werner and Wielinger's GOD/ POD technique. ${ }^{10}$ 


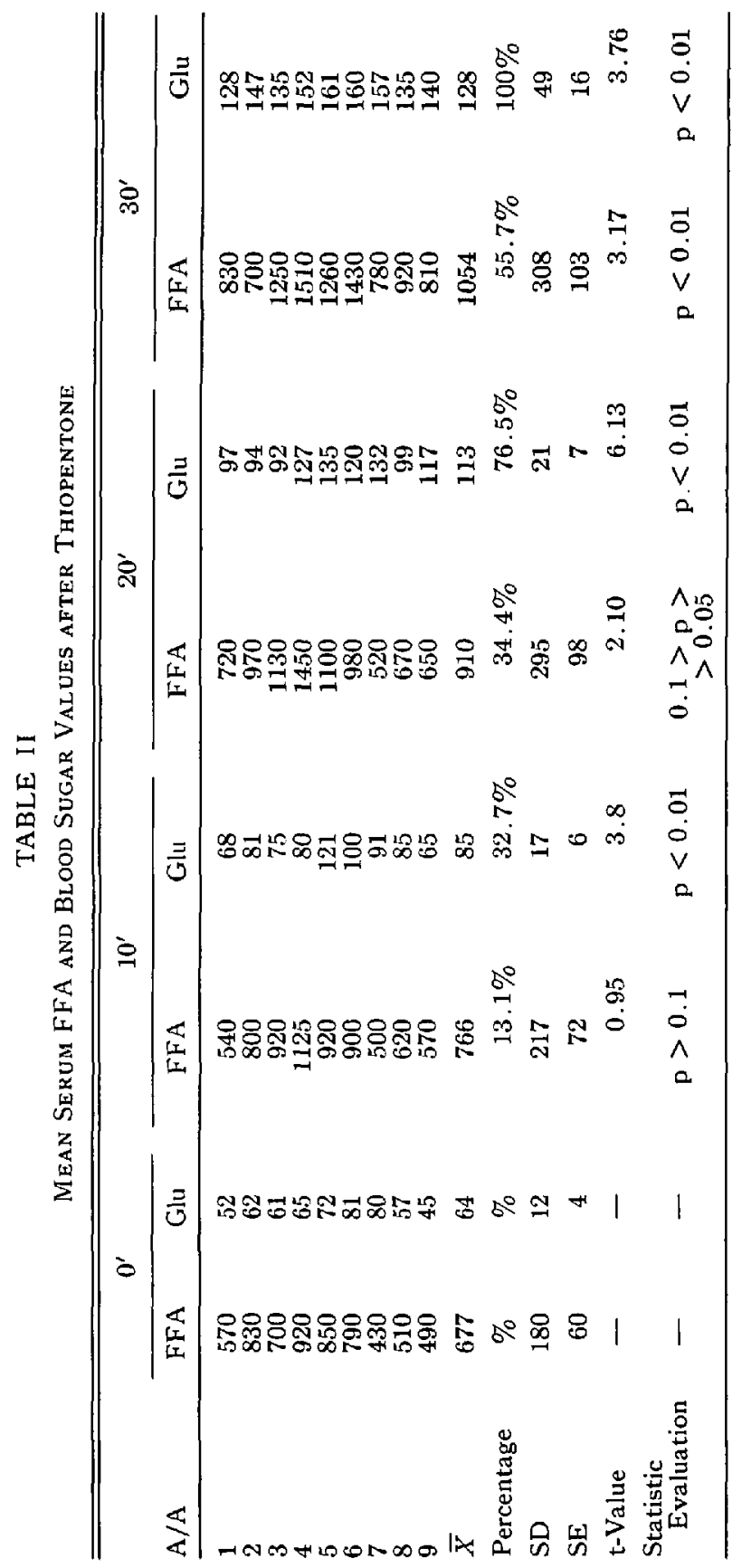




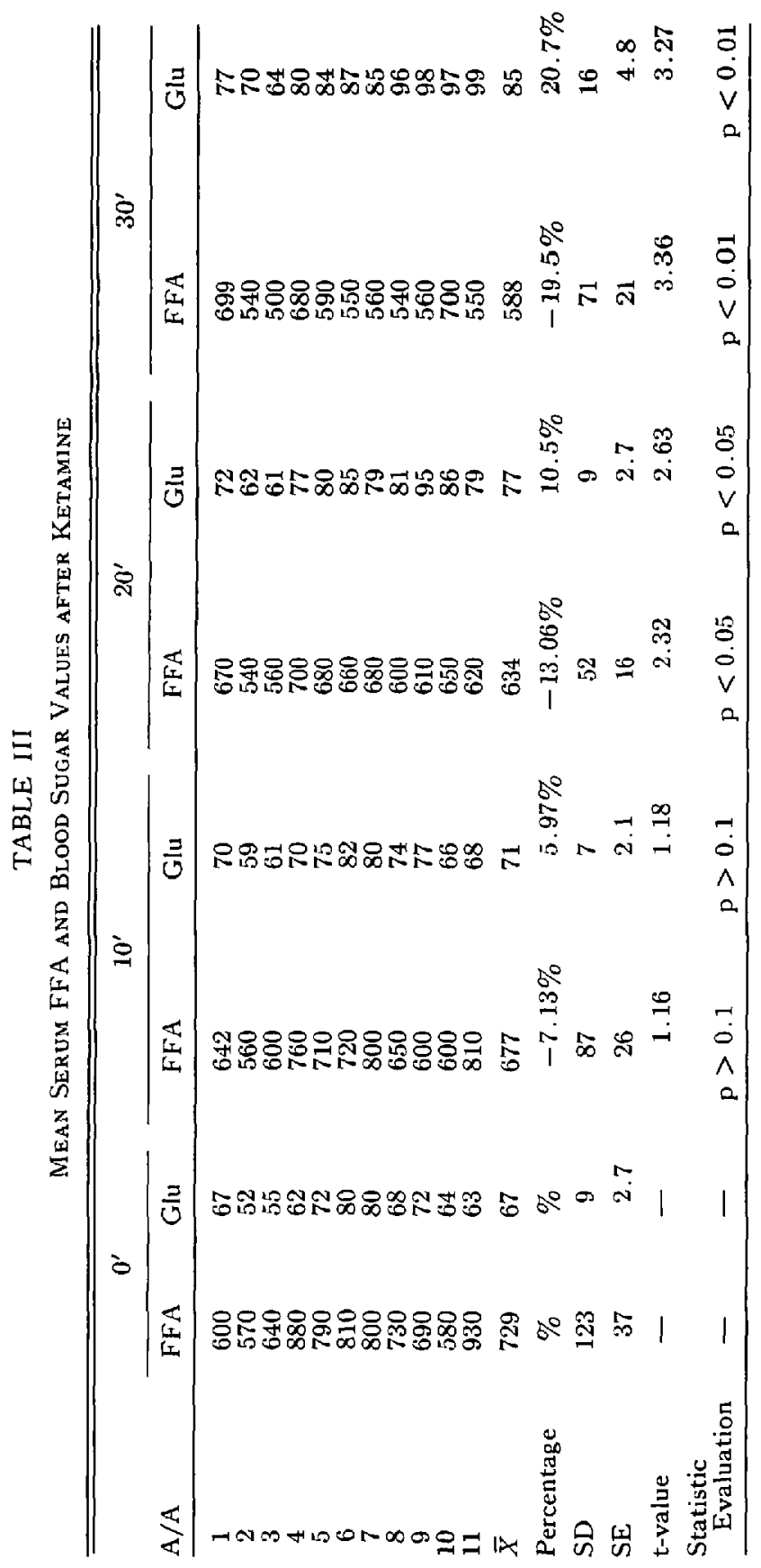


SERUM FFA LEVELS AFTER DIFFERENT ANAESTHETIC AGENTS

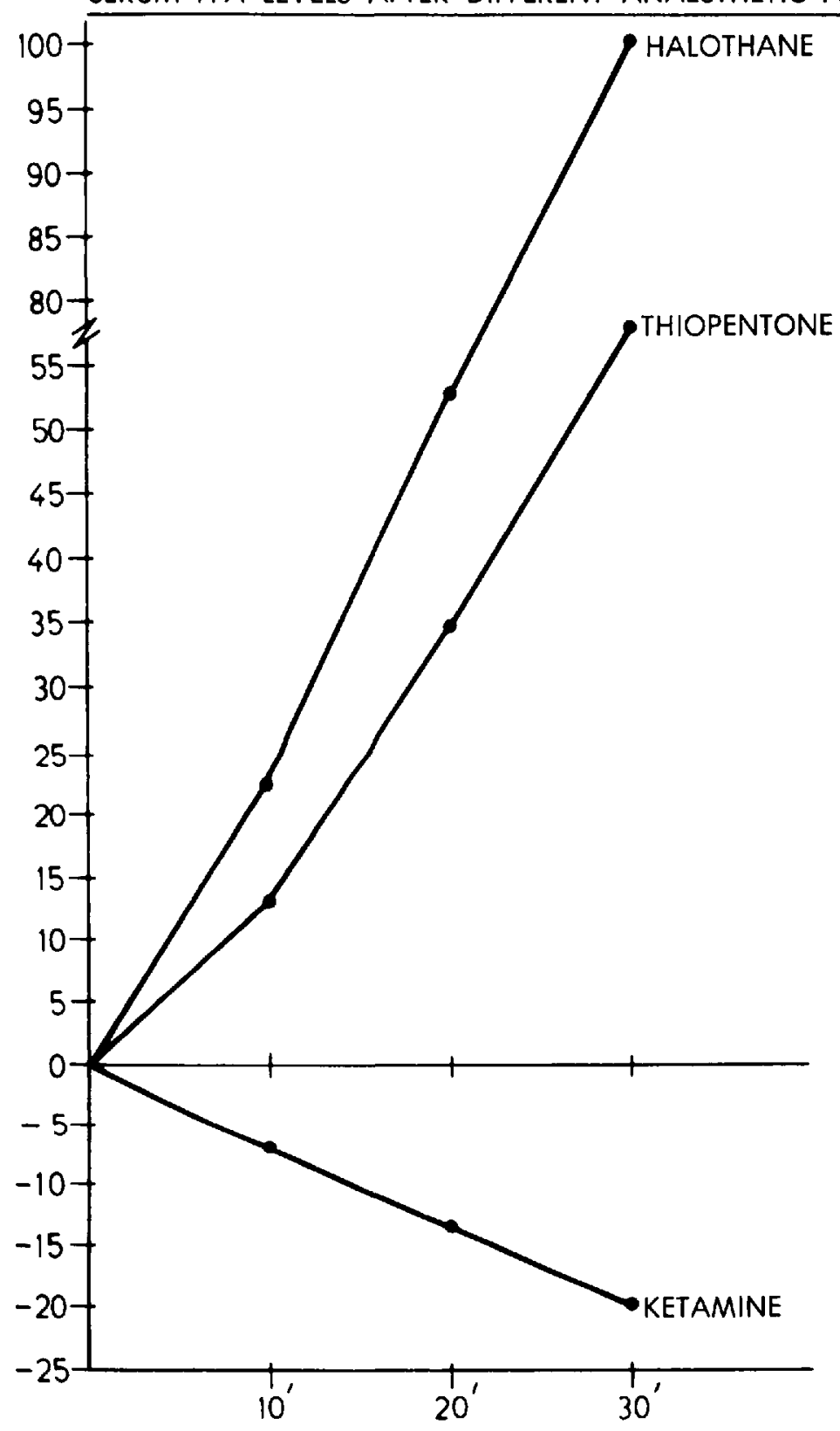

Fig. 4 


\section{BLOOD SUGAR CHANGES AFTER DIFFERENT ANAESTHETIC AGENTS}

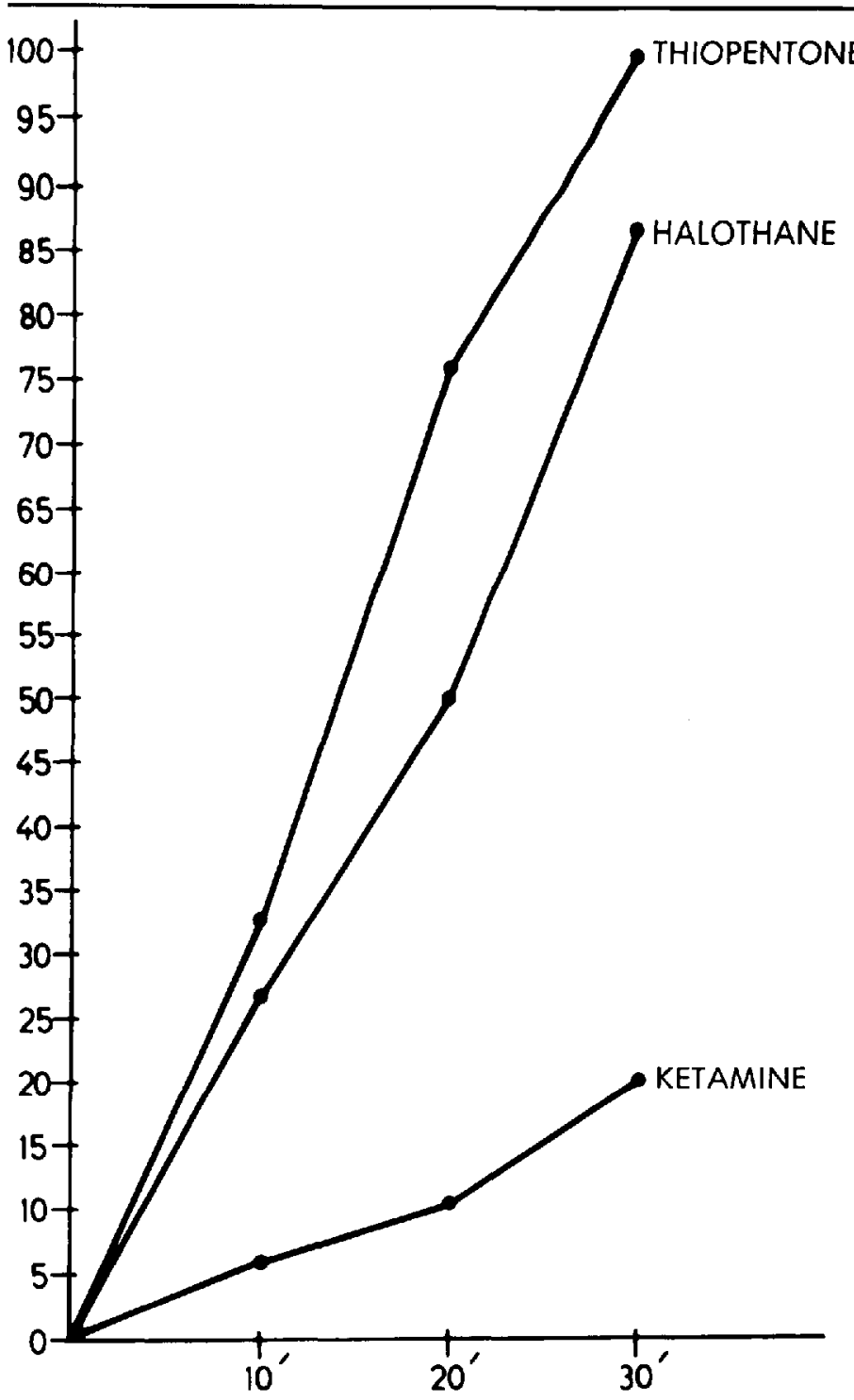

Fig. 5 


\section{RESULTS}

\section{Group 1 (Halothane)}

Free fatty acid and blood sugar levels were elevated 10, 20 and 30 minutes after induction (Table I and Figure 1). The mean values are statistically significant $(p<0.01)$ for both at the 30 -minute reading.

\section{Group 2 (Thiopentone Sodium)}

Again serum free fatty acid increased but to a lesser extent than in Group 1 halothane anaesthesia. There was also a remarkable increase of blood glucose levels and these were much higher than those observed under halothane anaesthesia. These values are also statistically significant $(p<0.01)$, for both at the 30-minute period (Table II and Figure 2).

\section{Group 3 (Ketamine- $\mathrm{HCl}$ )}

As shown in Table III, there are important observations. In this case, serum free fatty acids were decreased below control values while blood sugar was slightly increased but much less than in the halothane series and much lower than in the thiopentone group. Statistically, both values are significant $(\mathrm{p}<0.05)$ at 30 minutes (Table III and Figure 3). The mean values of serum free fatty acids and blood glucose for each group as percentage from control are shown in Figures 4 and 5.

\section{Discussion}

The above data demonstrate a hyperglycaemic effect of the three drugs used in our study. This was expected for halothane and thiopentone anaesthesia and confirms the reports of other investigators. ${ }^{11,12,5}$ It is remarkable, however, that ketamine also produces hyperglycaemia, albeit less marked than the two other drugs. The significance of this observation must be considered to be favourable from a practical point of view. Thus, if it is accepted as fact that halothane and thiopentone affect the sympathetic system, then ketamine would appear not to exert sympathetic metabolic action. ${ }^{7}$ Therefore, ketamine does not seriously impair peripheral glucose uptake. By the same token it can be said that ketamine might have less effect on basal metabolism as compared to the other drugs. The glucose assimilation coefficients with ketamine could be higher than with the other drugs, which means that cellular metabolism and especially biological oxidation is impaired less seriously.

As far as the effects on serum free fatty acid levels is concerned, it must be underlined that surgical stress might represent one of the main causes at least for the halothane and thiopentone groups, through activation of the sympathetic system, ${ }^{5}$ which in turn might increase the lipolysis, although this is not proven and would not explain the decreased free fatty acid levels in ketamine anaesthesia. This decrease might be attributed either to an increase of liposynthesis or to a decrease of lipolysis or both. It could be postulated also that either disturbance of the body basal metabolic state ${ }^{13-15}$ or a mechanism involving tissue cells is 
involved, but any attempt to explain the lowering effects of ketamine on free fatty acids is very difficult and the problem remains speculative for the time being, requiring further study on a biochemical level.

\section{SUMMaRY}

Serum free fatty acid and blood glucose levels were determined in 30 children under halothane, thiopentone and ketamine anaesthesia. Blood sugar is increased above baseline values by halothane 54.75 per cent $(+++)$, thiopentone 71.7 per cent $(++++)$ and ketamine 12.2 per cent $(+)$ anaesthesia. Serum free fatty acid was increased during halothane 58.7 per cent $(+++)$ and thiopentone 34.4 per cent $(++)$ anaesthesia, but was decreased with ketamine anaesthesia 13.4 per cent $(-)$.

It is assumed that several factors contribute to these changes and are related either to the sympathetic nervous system or basal metabolism and to the specifir actions of each drug.

\section{RÉSUMÉ}

Chez 30 enfants anesthésiés à l'halothane, au thiopentone et à la kétamine, on a mesuré le taux d'acide gras circulant et la glycémie. Ces trois agents augmentent la glycémie à des degrés divers: halothane 54.75 pour cent, thiopentone 71.7 pour cent et kétamine 12.2 pour cent. Le taux d'acide gras circulant augmente durant l'anesthésie à l'halothane (58.7 pour cent) et au thiopentone (34.4 pour cent) mais diminue durant l'anesthésie à la kétamine ( -13.4 pour cent).

Plusieurs facteurs contribuent à ces changements qui sont attribuables ou bien l'activité du système nerveux sympathique sur le métabolisme basal ou à l'action spécifique de chaque agent.

\section{REFERENCES}

1. Dobrin, A.B. \& Fedonuk, S.A. A comparison of the cardiovascular, respiratory and metaboflic effects of methoxyflurane and halothane in dogs. Anesthesiology 22: 355 (1961).

2. Gervenko, F.W. \& Grene, N.M. Effect of cyclopropane anesthesia on glucose assimilation coefficient in man. Anesthesiology 28: 914 (1967).

3. Galla, S.I. Glucose pool size, turnover rate and $\mathrm{CO}_{2}$ production during halothane anesthesia in dogs. Anesthesiology 28: 251 (1967).

4. Galla, S.J. \& WiLson, E.F. Hexose metabolism during halothane anesthesia in dogs. Anesthesiology 25: 96 (1964).

5. KEAting, V., et al. Halothane and carbohydrate metabolism. Anesthesia 14: 268 (1969).

6. Martinez, C. Effect of barbituric acid on alloxan diabetes in rats and dogs. Am. J. Physiology 182: 267 (1955).

7. Hensex, I., et al. Untersuchungen über Kreislauf- und Stoffwechselveränderungen unter Ketamine Narcose. Der Anaesthesist 21: 44 (1972).

8. Duncomb, W.G. Colorometric method of determination of plasma nonesterified fatty acids. Clinical Ch. Act. 9: 122 (1964).

9. Howonth, P.J.N., et al. Evaluation of a colorometric method of determination of plasma nonesterified fatty acids. Clinical chem. Act. 14: 69 (1966).

10. Werner, W., Rex, H.G., \& Wielinger, H. Properties of a new chromogen for the determination of glucose in blood according to the GOD/POD (Glucose oxidase-peroxidase) method. Fresenicus Z. Anal. Chem. 1970. 252 (2-3) 224-8 (Germ.).

11. Hunter, A.R. Halothane and blood sugar. Anesthesiology 31: 490 (1959). 
12. Kanianis, et al. Relation between glucose tolerance and serum insulin levels in humans before and after thiopental I.V. injection in humans. Acta Anesthesiologyca Hellenica 6: 163 (1973).

13. Bongman, R.L., et al. Effects of barbiturates on skeletal muscle function. Anesthesiology 21: 150 (1960).

14. Bontels, E.C. Basal metabolism testing under pentothal anesthesia. J. Clin. Endocrinology 9: 1190 (1949).

15. Brody, J.M. \& BaIn, S.A. Effect of barbiturates on oxidative Phosphorylation. Proc. Soc. exp. biol. Medicine 77: 50 (1957). 